\title{
LEGAL RECONSTRUCTION OF PHYSICAL CONSTRUCTION SERVICES BASED ON QUALITY OF PUBLIC SERVICES
}

\author{
Suyatim \\ Government employees in Pangalanbun \\ E-mail : suyatim1234@gmail.com
}

\begin{abstract}
Construction services are useful in terms of various means to support the achievement of national development goals. Regarding the services of this construction, stipulated in Act No. 18 of 1999 and its amendments, let the rules of its implementation. However, in the implementation can not run optimally, because there are obstacles, so it requires an effort for physical development services for the public benefit can be beneficial to the community. Quality of service in the public sector is a key word to revive public confidence in the government.
\end{abstract}

Keywords : Construction Services, Development, and Public Service

\section{A. INTRODUCTION}

A fact so far that national development has not been implemented properly in accordance with national objectives, this is caused by a variety of things that are complex, especially the weak law enforcement, the growth of culture of corruption, collusion, nepotism, and others . All the complexities of the problem have a major impact on the achievement of national goals.

In the field of construction services is also important to contribute to the birth of legal and social phenomena, although there has been a paradigm shift in the legal tool, but in practice is still apparent has not been implemented in accordance with the applicable law. Construction services is one of the activities in the economic, social, and cultural fields that have an important role in the achievement of various means to support the realization of national development goals. Through this sector, the physical progress of Indonesia's development can be seen directly from the existence of high buildings, bridges, infrastructure such as toll roads, telecommunications facilities, is the actual things that indicate the economic pulse of Indonesia is underway. ${ }^{1}$

In 1999, the government drafted a law on construction services, namely Law No. 18/1999

\footnotetext{
Nazarkhan Yasin, Mengenal Klaim Kontruksi \& penyelesaian Sengketa Kontruksi, Gramedia Pustaka Utama, Jakarta, 2004, page 226.
}

on Construction Services, followed by three Government Regulations as its implementing regulations, namely Government Regulation No. 28/2000 on Business and the Role of Construction Services Society, Government Regulation No. 29/2000 on the Implementation of Construction Services, Government Regulation No. 30/2000 on the Implementation of Construction Service Development, and Government Regulation Number 4 Year 2010 concerning Amendment to Government Regulation No. 28/2000 on Business and Role of Construction Services Society.

Background to the birth of the legislation on construction services is due to various laws and regulations that have been so far not oriented to the development of construction services in accordance with its characteristics. This has resulted in a less developed business climate that supports the improvement of competitiveness in an optimal and for the benefit of the community. ${ }^{2}$

As a juridical consequence of Law No. 18/1999, the Construction Service Development Institution (LPJK) was established as a determinant institution and has the competence to accredit the Association of Companies and Construction Services Associations which further became the basis of the Association of Companies

2 Salim HS., Perkembangan Hukum Kontrak Innominaat di Indonesia, Sinar Grafika, Jakarta, 2003, page 91. 
and Professional Association of Construction Services, previously this authority is entirely the authority of the government known as the List of Able Partner (DRM) issued by the governor in each province with certain procedures and requirements. $^{3}$

In the implementation of construction services in cooperation with government agencies / institutions in this case represented by the Committing Officer (PPK) as the official who will be responsible for the implementation of procurement of goods / services that will be done with the provider of construction services. The government is responsible for the implementation of construction services as a form of public service.

Based on the background for the above research, the writer can formulate some problems, Is the implementation of construction of physical construction has been running optimally. The factors that cause the need for legal reconstruction of the implementation of construction services of physical construction based on the quality of public services. And how is the reconstruction of construction service law the implementation of physical development based on the quality of public services can be applied fairly.

\section{B. DISCUSSION}

1. Implementation of physical construction construction has been running optimally

Construction services are construction planning consultancy services, construction service implementation services, and construction service supervision services. To undertake construction work between service providers and the government, based on contractual agreements or construction work contracts, ie agreements with which one party (the contractor), binds to conduct a work for another party (party to buy) by accepting a price determined. ${ }^{4}$

The beginning of a construction work, begins with an open auction generally held by a service or a state agency represented

3 Zahirman Zabir, Jasa Kontruksi Dalam Hukum Bisnis, Zahirman Zabir \& Associates Advocates \& Legal Consultan, Jakarta, 2004, page 4.

4 F.X. Djumialdi, Perjanjian Pemborongan, Cetakan Pertama, Bina Aksara, Jakarta, 1987, page 3. by a procurement committee attended by various bidders and won by one of the service providers who participated in the aforementioned. After the decision of the auction winner, then announced who the winner of the auction is located in the agency or institution that holds the auction mentioned. In the event that within 14 days no parties or other bidders are objected to the auction result of the auction winner, the auction winner has reached the final winner of the decision. Then after that, the service provider who won the auction signed a contract called a construction work contract that means the whole is a document that regulates the legal relationship between the Committing Officer and the service provider in the organization of the construction work.

The implementation of construction procurement in Indonesia has been specifically regulated in Law No. 18 of 1999 and has been revised by Law No. 2 of 2017. In terms of substance, except on the terms of contract law, the Act is quite complete arranging the procurement of construction services. In connection with the construction service provision, Perpres No. 54 of 2010 has used the term "construction work", the use of this term is different from that used in Presidential Decree Number 80 Year 2003. In terms of terminology, the term of chartering services is not appropriate because since its entry into force Law No. 18 of 1999 this term is not used anymore. The type of contract with the object of construction service work is a contract of construction work and not a contract of building construction as commonly used before the birth of this Act. ${ }^{5}$

The process of implementing a project needs to look at how a development project can be done effectively and efficiently in the achievement of a need. Effective work is meant that there is a need to activate as much as possible the existing resources (materials, equipment, materials, and workers), and efficiently intended to minimize

5 Yohannes S. Simamora, 2006, Hukum Kontrak (Kontrak Pengadaan Barang dan Jasa Pemerintah di Indonesia), Laksbang Justitia, Surabaya, page 213. 
any costs required for a project. In general, this process can work well, if the project implementer can maximize all the issues that support the workmanship, as well as a good working relationship with other work functions. Implementation of a project is always based on a work contract, where previously there was a pre-contract process. Pre-contract activities include all preparation and implementation of procurement of tender services, either through public auctions and limited auctions. ${ }^{6}$

In the development of the national construction industry today, the national construction industry is facing increasing demands and pressures. Globalization of world economy and finance has driven the growing demands of regional and global cooperation, through trade liberalization schemes of construction services such as GATS-WTO and AFAS-ASEAN. If there is no revamping of the institutional arrangement and the development of the business, labor, and the overall climate of construction services business, the wave of globalization with the liberalization package of trade in construction services will make Indonesia more and more dependent on foreign parties. Various infrastructure and properties will be made by foreign construction industries that have higher competitiveness. As a result, the Indonesian nation will spend more foreign exchange, and the security of the country (national security) will also become more vulnerable.

Related to the amount of corruption, collusion, and nepotism occurring in the construction sector today can be caused by distortions between the structure of the provider of construction services and market structure. Empirically, the structure of $90 \%$ construction service providers is dominated by small and medium-sized companies, while large enterprises account for only about $10 \%$. In contrast, the structure of the construction market shows that $60 \%$ is a small and medium

6 Wawancara dengan Staf pada Kementrian Pekerjaan Umum Dirjen SDA Balai Besar Wilayah Sungai SerayuOpak SNVT, Pelaksana Pengelolaan SDA Serayu-Opak, on 17 January 2017. class market, while the large class market is $40 \%$. Distortion occurs because $60 \%$ of the market is contested by $90 \%$ of companies. This condition practically causes businesses to do all kinds of ways to seize the market, including doing $\mathrm{KKN}$ with the users who provide the project. Therefore, it is necessary to revitalize the transformation of Indonesian construction in order to reduce this condition, for example by: (a) applying e-procure ment to government projects, (b) law enforcement and legislation, (c) encouraging service companies construction becomes a specialist, and (d) open access for the community to actively oversee the implementation of the project.

\section{Factors that cause the need for legal reconstruction of the implementation of physical construction construction services based on the quality of public services}

The key factor in the development of national construction services is the improvement of business capability, the realization of orderly construction work, as well as the increasing role of the community actively and independently. Increased business capability is supported by increased professionalism and increased business efficiency. While the realization of orderly construction work can be achieved, among others, through the fulfillment of rights and obligations and the existence of equality of the parties concerned.

Construction services have an important and strategic role in the achievement of various goals to support the realization of national development goals, where national development aims to create a just and prosperous society that is equally material and spiritual based on Pancasila and the 1945 Constitution.

The public has a role in the implementation of construction services work, among them to: (a) conduct supervision to realize the orderly implementation of construction services; (b) obtaining proper reimbursement for any losses directly incurred as a result of construction operations; (c) maintain order 
and comply with the provisions applicable in the field of construction services; (d) to prevent the occurrence of construction work that endangers the public interest. ${ }^{7}$

During the post-reform period of 1999, some government procurement arrangements have been issued, namely Perpres No. 80/2003, but the regulation still has weaknesses and has not been able to effectively prevent corruption, it is still possible for the procurement committee goods / government services to corrupt at every stage. Substituted by Presidential Regulation Number 54 Year 2010, there is a change of Presidential Decree Number 70 Year 2012 Article 1 paragraph (37) namely, procurement of goods / services implemented by using information technology and electronic transactions in accordance with the provisions of legislation or called e-procurement. Such revisions or amendments are made to the improvement or refinement of the arrangements at once to reduce some cases of Collusion and Nepotism Corruption $(\mathrm{KKN})$ that arise in the process of procurement of government goods and services.

The lack of transparency in government activities actually shows the common threads of fundamental issues in the practice of governance in Indonesia. Government practice in Indonesia has been a domain for bureaucratic and political elites. The arena of government and bureaucracy seems to be their own so they freely decide what they can know and which can be told to the citizens. Political and bureaucratic officials often forget that the power they have is actually giving citizens to serve and serve the citizens. The overwhelming concentration of power on the state represented by this bureaucratic and political elite allows them to freely determine the practice of governance and public services that are supposed to be designed to meet the needs and aspirations of the public shifted to the fulfillment of the needs of the government and its officials.

\footnotetext{
Interview with Staff at Ministry of Public Works Director General of SDA Serayu-Opak River Region of SNVT, Natural Resource Management Serayu-Opak, on 17 Januari 2017.
}

They tend to collect information in their hands and are reluctant to distribute it. They do so because in that way they can maintain power and interests.

\section{Reconstruction of construction service law of the implementation of physical construction based on the quality of public services can be applied fairly}

Due to the many opportunities of deviation in the procurement of government goods and services, the Corruption Eradication Commission (KPK), which also serves in the field of corruption prevention, concentrates to help solve the problem. E-procurement is a new system of procurement of goods and services that can shape government in terms of information transparency and web-based community services.

E-Procurement is currently one of the best approaches in preventing corruption in government procurement. In accordance with the Government Procurement Guidelines for Procurement of Goods and Services as stipulated in Presidential Decree No. 80 of 2003, with e-Procurement opportunities for direct contact between suppliers of goods and services with procurement committees become smaller, more transparent, more time efficient and cost and in easy implementation to conduct financial accountability. ${ }^{8}$

The selection of providers of goods and services using the e-Procurement system is applied to realize the objectives of effective and efficient, transparent, fair, non-discriminatory and accountable procurement of government goods and services.

In order to eliminate the inefficiency, monopoly, and corruption, collusion and nepotism practices in the construction services activities, detailed principles of disclosure have been formulated in the regulatory chapters which are expected to realize the orderly conduct of the construction service activities with the nuanced opportunity or fair opportunity for the community to participate

8 Interview with Staff at Ministry of Public Works Director General of SDA Serayu-Opak River Region of SNVT, Natural Resource Management Serayu-Opak, on 17 January 2017 
in the implementation of construction services work, fair competition among service providers, the equality of service users and providers in the rights and obligations, and to enhance compliance with laws and regulations.

Service excellence, competence, motivation, prosperity and sustainability are key words that challenge and hope for the internal strategic environment of $\mathrm{BP}$ Construction. Excellent service is a service that satisfies customers or clients in terms of time, costs and procedures. In addition to these three things, an important factor in the excellent service is the seriousness and presence of the heart in the sense of service efforts to customers is not solely because of duties and obligations, but because happy and happy to serve customers.

In the face of international competition, then that must be pursued, namely realizing the professionalism and competitiveness of construction services business parallel to the actors in the international market. From the business world of construction services is expected to grow awareness of business capability improvement, skills and skills through structuring and independent efforts. While the government provides support in the form of empowerment and regulation or use government projects as a vehicle to improve business skills, skills and work skills. These government measures are in line with various ratified international and regional treaties.

Accordingly, Article 3 and 88 paragraph (6) of Law Number 2 Year 2017 concerning Construction Services need to be reconstructed and supplemented so that the two articles read:

a. Article 3

The implementation of Construction Services aims to:

a) Provide the direction of growth and development of construction services to realize a strong business structure, reliable, highly competitive, and the results of quality construction services;

b) Realizing the order of construction services that ensures equality of service users and service providers in exercising their rights and obligations, and improving compliance in accordance with the provisions of laws and regulations;

c) Achieve increased public participation in construction services;

d) Arranging a system of construction services that is capable of realizing public safety and creating the comfort of the wired environment;

e) Ensure good governance of construction services; and

f) Creating value-added integration of all phases of the construction of physical construction services based on the quality of public services.

b. Article 88

(1) Disputes occurring in construction work contracts are settled with the basic principles of deliberation to reach consensus;

(2) In the event that the deliberations of the parties referred to in paragraph (1) can not reach a consensus, the parties take the stage of dispute resolution efforts contained in the construction work contract;

(3) In the case of dispute resolution efforts not listed in the construction work contract as referred to in paragraph (2), the parties to the dispute shall make a written agreement on the procedure for dispute resolution to be elected;

(4) The stages of dispute settlement efforts as meant in paragraph

(2) shall include:

a) Mediation;

b) Conciliation; and

c) Arbitration.

(5) In addition to the dispute resolution efforts referred to in paragraph (4) a and b, the parties may form a dispute board;

(6) In the case of dispute resolution 
efforts made by establishing a dispute board as referred to in paragraph (5), the election of the dispute board shall be conducted on the basis of the principle of professionalism and not part of either party, as well as in the dispute settlement of contract of construction work does not interfere with the running of public services;

(7) Further provisions on dispute settlement as referred to in paragraph (1) shall be regulated in a Government Regulation.

So that Article 3 and 88 of Law No. 2 of 2017 from the reconstruction can answer as well as provide a sense of justice for all parties, especially the wider community.

\section{CONCLUSION}

Implementation of physical construction construction has not been able to run optimally. An imbalance between the limited construction work or the project and the service provider results in bargaining power of the service provider is very weak. The concerns of not getting a job tendered by the service user or the project owner cause the service provider to accept the construction contract made by the service user. While the bidding process is usually a reluctant service provider to ask sensitive matters, such as the availability of funds, contract content, smooth payments, service providers are afraid of being blacklisted.

Factors that lead to the need for legal reconstruction of the implementation of physical construction services based on the quality of public services are inefficiency, monopoly, and corruption, collusion and nepotism practices in construction services activities, lack of opportunities or fair opportunities for communities to participate in the implementation of construction services work, unhealthy competition among service providers, and lack of compliance with laws and regulations.

The reconstruction of construction service law for the implementation of physical development based on the quality of public services in the form of reconstruction of values can be applied fairly by reconstructing the following matters: (a) increasing the competence of Indonesia's construction human resources on a national scale as well as on an international scale; (b) (C) improving the quality of training infrastructure and facilities, (d) improving the quality of training institutions and test / certification institutions, (e) applying sustainable concept/ green construction, (f) lack of access to the capital of the Construction Service Business Enterprise ( $\mathrm{g}$ ) it is necessary to provide construction services through the application of qualification / capability classification in the establishment of a construction service company; (h) prepare a construction service provider with high competitive in pa (i) the need for various innovations in infrastructure investment financing patterns, particularly public works infrastructure, $(j)$ the need to sharpen government support policies within the framework of Public Private Partnership (PPP) in order that the existing policies can be effective, and $(k)$ the need to encourage and facilitate the utilization of available funding sources for infrastructure investments. As for the legal reconstruction of legislation relating to construction services should be done reconstruction of Article 3 and Article 88 of Law No. 2 of 2017.

Strengthening and structuring of national construction services is needed as a foundation in building a robust construction industry and high competitive and independent in facing the flow of globalization. The institutional arrangements for the development of the construction industry need to be directed to be a professional organization in facilitating and promoting world-class construction industry and trade in the world.

The government should develop effective, efficient and integrated facilitation, technical and administrative mechanisms through cooperation and coordination between Satminkal Ministry of Public Development, Ministry / LPND and other institutions related to the development of construction services.

The central government should improve the construction of construction in a transparent and open manner by involving the community and increasing the role of local government in the form of deconcentration / assistance tasks. 


\section{BIBLIOGRAPHY}

A. Stauss and J. Corbin Busir. 1990. Qualitative Research : Grounded Theory Prosedure and Technique. London : Lindon Sage Publication.

F.X. Djumialdi. 1987. Perjanjian Pemborongan, Cetakan Pertama. Jakarta : Bina Aksara.

Mattew B. Miles \& A. Michael Huberman. 1992. Analisis Data Kualitatif. Jakarta : UI Press.

Nazarkhan Yasin. 2004. Mengenal Klaim Kontruksi \& penyelesaian Sengketa Kontruksi. Jakarta : Gramedia Pustaka Utama.

Salim HS. 2003. Perkembangan Hukum Kontrak Innominaat di Indonesia, Jakarta : Sinar Grafika.

Soerjono Soekanto dan Sri Mamudji. 2003. Penelitian Hukum Normaif, Suatu Pengantar Singkat. Jakarta : Raja Grafindo Persada.

Yohannes S. Simamora. 2006. Hukum Kontrak (Kontrak Pengadaan Barang dan Jasa Pemerintah di Indonesia). Surabaya : Laksbang Justitia.

Zahirman Zabir. 2004. Jasa Kontruksi Dalam Hukum Bisnis, Jakarta : Zahirman Zabir \& Associates Advocates \& Legal Consultan.

Undang-Undang Dasar Negara Kesatuan Republik Indonesia Tahun 1945.

Undang-Undang Nomor 18 Tahun 1999 jo. Undang-Undang Nomor 2 Tahun 2017 tentang Jasa Konstruksi.

Peraturan Pemerintah Nomor 28 Tahun 2000 tentang Usaha dan Peran Masyarakat Jasa Konstruksi.

Peraturan Pemerintah Nomor 29 Tahun 2000 tentang Penyelenggaraan Jasa Konstruksi.

Peraturan Pemerintah Nomor 30 Tahun 2000 tentang Penyelenggaraan Pembinaan Jasa Konstruksi.

Peraturan Pemerintah Nomor 4 Tahun 2010 tentang Perubahan atas Peraturan Pemerintah Nomor 28 Tahun 2000 tentang Usaha dan Peran Masyarakat Jasa Konstruksi. 